\title{
Bioconversion of Fish Hatchery Waste as Feed in the Production of Live Feed
}

\author{
Sujjat Al Azad*, Al-Najib Bin Benjamin, Mohammad Tamrin Bin Mohamad Lal \\ Borneo Marine Research Institute, University Malaysia Sabah, Kota Kinabalu, Malaysia \\ Email: *sujjat@ums.edu.my
}

How to cite this paper: Al Azad, S., Benjamin, A.-N.B. and Lal, M.T.B.M. (2020) Bioconversion of Fish Hatchery Waste as Feed in the Production of Live Feed. $A d$ vances in Bioscience and Biotechnology, 11, 289-300.

https://doi.org/10.4236/abb.2020.117021

Received: June 7, 2020

Accepted: July 10, 2020

Published: July 13, 2020

Copyright $\odot 2020$ by author(s) and Scientific Research Publishing Inc. This work is licensed under the Creative Commons Attribution International License (CC BY 4.0).

http://creativecommons.org/licenses/by/4.0/

\begin{abstract}
Purple Non-Sulfur Bacteria (PNSB), also known as phototrophic bacteria are widely distributed in both freshwater and marine environment and capable to grow in wide range of substrates. In this study, Bacterium Rhodobacter sphaeroides strain UMS2, a freshwater isolate was used in this study in utilization of fish hatchery waste. This study was conducted to determine the nutritional values of bioprocess product that was grown in fish hatchery waste. Finally, the waste bio-converted product was used as feed supplement to monitor the growth performance of live feed Tubifex spp. Inoculum of Rhodobacter sphaeroides strain UMS2 was developed in 112 synthetic media and 48-h culture of $30 \%(\mathrm{v} / \mathrm{v})$ inoculum was used in fish hatchery waste during the bioprocess. The nutritional values of bio-converted product, except total ash (\%), were not significantly improved with $30 \%(\mathrm{v} / \mathrm{v})$ inoculum of Rhodobacter sphaeroides, strain UMS2. Feeding trial in bloodworm (Tubifex spp.) with bioconversion product conducted for 15 days to monitor growth (w/v) of live feed. Initial growth $1.42 \pm 0.001 \mathrm{~g} / \mathrm{L}$ of Tubifex spp. was stocked in $15 \times 75 \times 15 \mathrm{~cm}$ plastic tray connected with recirculated system. Tubifex spp. was observed to be comparatively higher $(1.55 \pm 0.12 \mathrm{~g} / \mathrm{L})$ while fed in the product that contained bacterium than the growth $(1.44 \pm 0.15 \mathrm{~g} / \mathrm{L})$ of Tubifex spp. fed in the bioconversion product of without bacterium. The inoculums size $(30 \%)$ of bacterium not enough to support the growth of Rhodobacter sphaeroides, strain UMS2 in the bioconversion process to improve the nutritional values. However, while used as feed supplement it improved the growth performance of the Tubifex spp. So, bacterium Rhodobacter sphaeroides, strain UMS2 has potentiality to be used as feed supplement in the production of live feed.
\end{abstract}

\section{Keywords}

Hatchery Waste, Bioprocess, Microbe and Live Hatchery Waste, Bioprocess, Microbe and Live Feed Growth 


\section{Introduction}

The waste generated from fish hatchery mainly contained $7 \%-32 \%$ of the total nitrogen and $30 \%-84 \%$ of the total phosphorus [1]. Nutrient rich waste in long run if discharged that ultimately causes eutrophication problem. Most of the hatchery designed to save water in a recirculation system. The conventional method for the treatment of wastewater in a recirculation process which includes solids removal, ammonia oxidation, aeration and disinfection [1]. Two types of waste generated from UMS finfish hatchery, soluble and solid waste and they are both organic and inorganic. The wastewater from UMS finfish hatchery is not different from that of a production farm in terms of quality and quantity of waste. The wastewater from UMS finfish hatchery not only generated from larval rearing and fry production units, but also from other culture units [2]. The concentration of dissolved inorganic nutrients, such as ammonia of $4.38 \mathrm{mg} / \mathrm{L}$, nitrate $(3.37 \mathrm{mg} / \mathrm{L})$ and phosphate of $8.55 \mathrm{mg} / \mathrm{L}$ in UMS hatchery were observed higher [2] compared to that reported by other researchers [3]. The nutrients rich nonconventional resource can properly be utilized into value added substances. It is therefore necessary to develop new research application of converted this waste to a value-added product rather than to use uneconomic conventional method for treatment.

Purple non-sulfur bacteria the largest group in phototrophs are the potential species to convert wastes into values added product. Bioconversion of waste has been proven to be effective in the increase of nutrients in culture media. Purple non sulfur bacteria (PNSB) capable in bio-conversion of agro-based industrial waste into nutritionally value added product [4]. This group of bacteria grew well in wastewater could have two folds benefit: production of single cell protein and the cost of wastewater treatment could be reduced. PNSB bacterium Rhodovulum sulfidophilum for production of bacterial biomass with concomitant treatment of sardine processing effluent [5], Rhodocyclus gelatinosus as best substrate for biomass production dilution of tuna condensate 1:10 (v/v) with shrimp blanching [6], Afifella marina strain ME (KC205142) production of exopolymeric substances [7], Rhodobacter sphaeroides strain UMSFW1 production of biomass with the reduction of chemical oxygen demand in Palm Oil Mill effluent [8], Rhodopseudomonas spp. for the production of biomass and carotenoids in synthetic sugar wastewater [9], Rhodobacter blasticus and Rhodobacter capsulatus in the reduction of pollutant load in swine wastewater [10], production of Rubrivivax gelatinosus in poultry slaughterhouse wastewater [11] and mixed photosynthetic bacteria in treatment of agrobased industrial wastewater with the production of single cell protein [12] are well documented. In addition, waste grown PNSB biomass are rich in especially crude protein can be used as feeding additive and diet of cultured animal to reduce the cost and provide better nutritional composition of cultured animals. The self-flocculated bacterium Rhodovulum sp. is not only rich in high quality protein, but also contains significantly large amounts of carotenoid pigments, biological co-factor and vitamins 
that might enhance the growth and survival in fish [13]. Bacterial cells Rhodobacter sphaeroides, grown in pineapple wastewater and Rhodocyclus gelatinosus cells grown in cassava waste used in diets improves the growth red tilapia and fancy carp [14], fish growth hormone gene into Rhodobacter sp. strain NKPB0021 in diets accelerate the growth of fish [15], Rhodospirillum rubrun with fish meal improves the growth and survival of juvenile fresh water prawn [16], Rhodovulum sulfidophilum combined with commercial tilapia feed improves the skin pigmentation and growth [17], $R$. sulfidophilum with Skeletonema costatum supported better growth and survival of $P$. monodon larvae reared from the naupliar to post-larval stage [18] and improvement in growth and survival in Asian sea bass larvae in $R$. sulfidophilum sp. [19] have reflected the uses of PNSB in aquaculture industry. However, Information is limited in the use purple nonsulfur bacteria to utilize fish hatchery waste in the bioprocess to improve the nutritional values of biomass and possibility to be uses as feed supplement in live feed production for aquaculture industry. Aquatic worm, Tubifex spp. is one of the potential live feed in aquarium industry. Until now this live feed comes from the wild harvest which is unreliable, inadequate, have many parasite and diseases and hazardous to collect for unhealthy conditions [20]. It is essential to develop a technique for mass production of Tubificid to get reliable supply of the growing demand of this live feed in controlled environment. No information is available on the use of live feed, Tubifex spp. grown on derived product from bioprocess fish hatchery waste. This study was conducted to determine the nutritional values of products derived from the bioprocess of hatchery waste with $R$. sphaeroides Strain UMS2 and suitability to use as feed supplement in production of live feed.

\section{Materials and Methods}

\subsection{Collection of Fish Hatchery Waste (FHW)}

Fish Hatchery Waste (FHW) was collected from the Fish Hatchery of University Malaysia Sabah, Sabah. Only discarded or thrown FHW was collected from the area such as in tank culture of freshwater species, Tilapia and Catfish. The collected FHW was immediately transported to Borneo Marine Research Institute (BMRI) Biotechnology Laboratory for further process. The FHW then placed into the oven for complete dry at $70^{\circ} \mathrm{C}$ for $24 \mathrm{~h}$ and grinded into fine powder (smaller than $300 \mathrm{~mm}$ ). Dried Hatchery Waste Powder (HWP) was used in bioconversion process.

\subsection{Preparations of Inoculums}

Purple non-sulfur Bacterium, Rhodobacter sphaeroides Strain UMS2 was taken from the Borneo Marine Research Institute (BMRI) culture collection, which was isolated from mud of College Excellent in Campus of University Malaysia Sabah (UMS). The bacterium was incubated in 112 synthetic media for inoculums preparation. Synthetic 112 media is specific media used for the better 
growth of purple non-sulfur bacteria. The composition of 112 media was yeast extract $(10 \mathrm{~g})$, di-potassium hydrogen sulphate $(1 \mathrm{~g})$ and magnesium sulphate $(0.5 \mathrm{~g})$. All the ingredients of 112 synthetic media were mixed well in one-liter distilled water and $29 \mathrm{ml}$ was dispensed into several $30 \mathrm{ml}$ universal bottles. The bottles were autoclaved at $121^{\circ} \mathrm{C}$ for 15 minutes for inoculum preparation. From the stock one $\mathrm{ml}$ of the stock culture was dispensed in $29 \mathrm{ml}$ of previously autoclaved universal bottles contained 112 media and incubated anaerobic under 2500 lux of light intensity at $30^{\circ} \mathrm{C} \pm 2^{\circ} \mathrm{C}$ for 72 -h. Subsequently inoculum was developed in $1 \mathrm{~L}$ Schott bottle. The inoculum developed in $30 \mathrm{~mL}$ was used to make $100 \mathrm{~mL}$ inoculum and 48 -h culture of $100 \mathrm{~mL}$ inoculum was used to prepared $1 \mathrm{~L}$ inoculum.

\subsection{Bioprocess of Hatchery Waste Powder (HWP)}

$20 \mathrm{~g}$ of previously dried hatchery waste powder (HWP) was mixed in $800 \mathrm{ml}$ of 112 synthetic media in 1-liter Schott bottle. Rhodobacter sphaeroides inoculums of $30 \%$ from 48 -h culture was inoculated into each bottle. The bottles were incubated aerobically under 2500 lux of light intensity at $30^{\circ} \mathrm{C} \pm 2^{\circ} \mathrm{C}$ for 6 days. The products derived from the bioprocess of HWP was collected after centrifuged at $4000 \mathrm{rpm}$ for 30 minutes. The obtained biomass was dried to a constant moisture level in oven at $60^{\circ} \mathrm{C} \pm 1^{\circ} \mathrm{C}$. The powder biomass was packed in airtight seal plastic bag and kept at room temperature until used.

\subsection{Feeding Trial in Bloodworm (Tubifex sp.) Using Bioprocess HWP Derived Product}

Two diets were used in feeding trial. Diet 1 HWP derived product with bacterium (Rhodobacter sphaeroides) and Diet 2 without bacterium of Rhodobacter sphaeroides. The diets without bacteria content (Rhodobacter sphaeroides) that derived from the bio-converted products used as the control. The both diets were grinded and used to feed Tubifex spp. in powder form. Feeding trial was conducted in Integrated Multi-trophic Aquaculture (IMTA) research area at University Malaysia Sabah, Malaysia.

\subsection{Other Experimental Protocols in Feeding Trial}

Culture unit: Tubifex spp. was in plastic tray, size of $15 \times 75 \times 15 \mathrm{~cm}$, and with water depth of $10 \mathrm{~cm}$ with closed recirculating system. Fine sand was used as substrate to settle Tubifex spp.

Collection: Tubifex worm was purchase from local markets. They were placed in a beaker and randomly taken for stocking. Initial growth of $1.42 \pm 0.001 \mathrm{~g} / \mathrm{L}$ of Tubifex spp and was stocked at the rate of $2.5 \mathrm{mg} / \mathrm{cm}^{2}$ in culture tray.

Feeding: The worms was fed with $10 \mathrm{~g}$ (dry wright) of diets two times in a day (8:00 am and 4:00 pm). During feeding the water flow was stopped for $20 \mathrm{~min}$.

Culture condition: The water flow rate of $1.23 \pm 0.33 \mathrm{~L} / \mathrm{min}$ was maintained to keep up dissolved oxygen between $5-6 \mathrm{mg} / \mathrm{L}$. The temperature $25^{\circ} \mathrm{C}-27^{\circ} \mathrm{C}$ was maintained in production of Tubifex worm. 
Duration: Experiment was conducted for 15 days, in the month of July 2019 with three replications. Final total weight $(\mathrm{g} / \mathrm{L})$ was taken with balance at the end of experiment.

\subsection{Analytical Parameters}

The proximate compositions of initial and bioprocessed product were carried out with the standard methods [21]. Estimation of crude protein (\%) was done using KjeltecTM 2300 Auto-analyzer Unit, crude fiber (\%) after hydrolysis with strong acid and alkali using FibertecTM 1020 and crude lipid (\%) extracted in petroleum ether using SoxtecTM System 2043 Extraction Unit of Foss Tecator, Sweden, and crude ash (\%) was determined using muffle furnace.

\subsection{Statistical Analysis}

T-test was used to determine significance difference (5\% level) between the growth performances of bloodworm (Tubifex sp.) fed with two diets using SPSS version 24 .

\section{Results}

Ash and crude protein are the major component obtained in Hatchery Waste Powder (HWP) was used in the bioprocess (Table 1). At the end of 6th day, the derived product that was harvest after bioprocess with Rhodobacter sphaeroides shows very little improvement except ash (Table 2). On the other hand, reduction of crude fiber from $1.02 \%$ to $0.03 \%$ as observed same in the derived product bioprocessed with bacterium and without bacterium. However, proximate compositions of the bioprocess HWP were increased, except crude fiber while PNSB bacterium Rhodobacter sphaeroides was used as inoculum (Table 2).

At the end of 15 days experiment the mean final weight of Tubifex spp. was observed significantly higher while fed with Diet 1 (derived product with Rhodobacter sphaeroides) than fed with Diet 2 (derived product without Rhodobacter sphaeroides). There observed significantly differences $(\mathrm{F}=15.63 ; \mathrm{p}=0.00)$ in the growth performance in live feed fed with Diet 1 and Diet 2 (Table 3).

Table 1. The proximate compositions of Hatchery Waste Powder (HWP).

\begin{tabular}{|c|c|c|c|c|c|}
\hline Type of Waste: & Crude protein (\%) & Crude ash (\%) & Crude lipid (\%) & Crude fiber (\%) & Moisture (\%) \\
\hline $\begin{array}{l}\text { Hatchery Waste } \\
\text { Powder (HWP) }\end{array}$ & 19.78 & 34.58 & 5.85 & 0.07 & 5.73 \\
\hline
\end{tabular}

Table 2. Proximate composition of derived products after bioconversion of Hatchery Waste Powder (HWP) with Rhodobacter sphaeroides.

\begin{tabular}{|c|c|c|c|c|c|c|c|c|c|c|}
\hline \multirow{2}{*}{$\begin{array}{l}\text { Rhodobacter } \\
\text { sphaeroides }\end{array}$} & \multicolumn{2}{|c|}{ Crude protein (\%) } & \multicolumn{2}{|c|}{ Crude ash (\%) } & \multicolumn{4}{|c|}{ Crude lipid (\%) Crude fiber (\%) } & \multicolumn{2}{|c|}{ Moisture } \\
\hline & Day 0 & Day 6 & Day 0 & Day 6 & Day 0 & Day 6 & Day 0 & Day 6 & Day 0 & Day 6 \\
\hline With bacterium & 19.78 & 20.90 & 34.58 & 89.52 & 5.85 & 5.90 & 1.02 & 0.32 & 5.73 & 4.65 \\
\hline Without bacterium & 19.78 & 19.88 & 34.58 & 59.90 & 5.85 & 5.88 & 1.02 & 0.32 & 5.73 & 3.12 \\
\hline
\end{tabular}


Table 3. Growth performance of live feed, Tubifex spp while fed with two types of diets.

\begin{tabular}{ccc}
\hline Diets & Initial weight of Tubifex $(\mathrm{g} / \mathrm{l})$ & Final weight of Tubifex $(\mathrm{g} / \mathrm{l})$ \\
\hline $\begin{array}{c}\text { Diet 1 derived product with } \\
\text { Rhodobacter sphaeroides }\end{array}$ & $1.42 \pm 0.001^{\mathrm{a}} \mathrm{g} / \mathrm{L}$ & $1.55 \pm 0.12^{\mathrm{a}} \mathrm{g} / \mathrm{L}$ \\
$\begin{array}{c}\text { Diet 2 derived product without } \\
\text { Rhodobacter sphaeroides }\end{array}$ & $1.42 \pm 0.001^{\mathrm{a}} \mathrm{g} / \mathrm{L}$ & $1.44 \pm 0.15^{\mathrm{b}} \mathrm{g} / \mathrm{L}$
\end{tabular}

Values are express mean \pm SD, different subscript shows significant differences.

\section{Discussion}

The variation in the organic and inorganic composition of finfish wastes are influenced by certain factors, such as, types of rearing tank, culture techniques, types of species and sizes of species, feed types and feed management, dynamics of nutrient in circulation and utilization, species handling techniques and the other physical chemical environment of the culture areas [22]. The concentration of nutrients in aquaculture system increased with excess use of feed that remains un-eaten as well from the accumulation of fish excreta until bacterial activity. Total solids generated in any aquaculture system from the uneaten fraction of feed as well as the excreted product from the fish gradually dissolved in water and increase the inorganic component so nutrients. The solid generated in UMS hatchery in the range of $75-82 \mathrm{mg} / \mathrm{L}$ comparatively higher [2] than reported by other researchers. The concentration of DIN, such as ammonia of 4.38 $\mathrm{mg} / \mathrm{L}$, nitrate $(3.37 \mathrm{mg} / \mathrm{L})$ and phosphate of $8.55 \mathrm{mg} / \mathrm{L}$ in UMS hatchery were observed higher [2]. Normally the concentration of nutrients in were in the range of $0.12-14.7 \mathrm{mg} / \mathrm{L}$ of $\mathrm{NH}_{4}-\mathrm{N}, 0.02-1.5 \mathrm{NO}_{2}-\mathrm{N} \mathrm{mg} / \mathrm{L}, 0.01-5.3 \mathrm{mg} / \mathrm{L}$ of $\mathrm{NO}_{3}-\mathrm{N}$, and $3.1-17.7 \mathrm{PO}_{4}-\mathrm{P} \mathrm{mg} / \mathrm{L}$ [3]. In addition, opportunistic microbes in the system start to breakdown solids and converted into bacterial biomass while reducing the DIN in water. Nutrients compositions are important in further use of these wastes to convert value added products in bioconversion process. Purple non-sulfur bacteria (PNSB) are well known with its bio-transformation characteristic due availability in wide range of natural inhabitant [23] PNSB also known as well with their characteristic organic transformation [24]. The purple non-sulfur bacterium, Rhodobacter sphaeroides was expected to be increased the nutritional value of hatchery waste; in term of dry biomass such as crude protein, crude lipid and crude ash; under standard liquid state fermentation with light intensity of 2500 lux at $30^{\circ} \mathrm{C} \pm 2{ }^{\circ} \mathrm{C}$ temperature [25]. Thus, the UMS fish hatchery effluent possesses more than sufficient nutrients to support the growth PNSB that can be used as substrate in culturing Rhodobacter sphaeroides Strain UMS2 for the production of bacterium biomass in controlled environment [2]. Under the presence of Rhodobacter sphaeroides, the higher amount crude protein of hatchery waste biomass was expected, but it shows little improvement in present study. It indicated bacteria was unable to growth in this bioprocess system. The bacteria that inoculated might convert some hatchery waste protein or other nitrogenous compounds that available in environment into cell protein for 
microbial biomass production. Low performance in the improvement of protein reflects the growth of other opportunistic bacteria that remain in the HWP. The inoculum sizes used in present study was $30 \%(\mathrm{v} / \mathrm{v})$, might not enough to support to utilize the substrate in bioconversion process, fail to convert nutrients into biomass protein. Not only protein other nutritional components like fiber and lipid also did not improved at desired levels, with $30 \%(\mathrm{v} / \mathrm{v})$ inoculum. Nutritional values of vegetable waste during bioprocess with PNSB bacterium was observed better with $30 \%$ level of inoculum Afifella marina strain ME. The highest crude protein of $18.95 \%$ was recorded with $30 \%$ inoculum size. The crude lipid increased the highest value at $1.70 \%, 1.65 \%$ and $1.49 \%$ for $10 \%, 20 \%$, and $30 \%$ inoculum respectively. The maximum crude ash yielded $32.55 \%$ with inoculum size of $30 \%$ level of inoculum Afifella marina in bioprocess of vegetable waste [25]. Optimum size of inoculum is important because generally, the bacterial population is strongly heterogeneous and it takes time for all sub-populations to adapt to the new conditions. Soon et al. (2013) [26] The inoculum size of $20 \%(\mathrm{v} / \mathrm{v})$ Afifella marina used to observe the effect of light intensities and photoperiod of production of extracellular nucleic acids. Growth characteristic of Afifella marina strain ME (KC205142), as well as production of exopolymeric substances like enzymes and nucleic acid has been documented [7]. The increment of crude protein observed under the presence of bacteria might be due to the increasing of biomass of with higher level of inoculum [27]. The inoculated bacteria might convert some waste protein or other nitrogenous compounds available in the environment into cell protein for microbial mass production [28]. Other than inoculum sizes the optimum period in bioprocess for crude protein production is day 6 in current study was shorter than reported by other researcher [28], which suggested best harvesting on day 8 and day 7 for maximum crude protein production. The optimum proteolytic activity was recorded at $48 \mathrm{~h}$ of incubation, which also explains the high level of crude protein at Day 4 [7]. In addition, the extracellular proteases within the bacterium extracellular polymeric substances matrix play an important role in providing nutrients and alter extracellular polymeric substances composition [7]. However optimum time for incubation in present study was not taken in account which need further investigation.

Growth characteristics of live feed like Tubifex spp. depend on the media or substrate and other environmental parameters of the culture condition. The mean final weight of Tubifex spp. in present feeding trial was observed $1.55 \mathrm{~g} / \mathrm{L}$ significantly higher while fed with Diet 1 (derived product with Rhodobacter sphaeroides) than growth of $1.44 \mathrm{~g} / \mathrm{L}$ while fed with Diet 2 (derived product without Rhodobacter sphaeroides) at the end of 15 days. T. Tubifex grew slowly and attained a body weight of about $1.5 \mathrm{mg}$ during the initial period of 28 days; this was followed by the logarithmic growth phase for a subsequent period of 14 days; after the 42nd day the maximum body weight stabilized at around $7.5 \mathrm{mg}$ [29]. In this aspect the growth observed in present is seems satisfactory. The op- 
timum parameter to grow are concentration of dissolved oxygen in the range of $6-7 \mathrm{mg} / \mathrm{L}$, pH $7.0-7.2$, water temperature $27.5-28.0$, with flow rate of 200 to $250 \mathrm{ml} / \mathrm{min}$ [30], which was also maintained in present study. The worms selectively ingest silt and clay particles at depth and digest the attached microflora, primarily bacteria. They fed on the organic material, algae and bacteria lived in the sediment. Tubificid fed on the organic debris and bacteria lived in the sediment, but also fed on decayed vegetable waste [31]. Species of tubificid worms able to feed on waste organic materials such as sewage sludge and cattle excrement. The use of organic fertilizers in culture media including the wastes/faeces of quail, goat and chicken mixed with the rejected bread and tofu so far been conducted as the use of organic fertilizer could impact the growth performance and nutrients content of T. Tubifex [32]. Growth performance in present study indicated that diet composed of purple non-sulfur bacterium, Rhodobacter sphaeroides performed better than the diet composed without Rhodobacter sphaeroides in feed. Tubifex worms fed with decayed vegetables and yeast had growth higher than fed with minced fish and jellies, but no significant differences were observed between fed with decayed vegetables and yeast [31]. Fermented organic matter as substrate for the production and improve the nutritional values of $\mathrm{Tu}$ bificid worms. The fermented process includes preparation of fermented molasses, water, and probiotic activator which are bacteria Sacharomy cescerevisae and Lactobacillus sp. [32]. The fermentation of the organic matter has been proven to be effective in the increase of the nutrient of culture media. During fermentation the organic matter would be easily digested and used for having experienced alteration by the bacteria [33]. No information available regarding the probiotic effects of PNSB live feed sector. However, PNSB while used as feed additive it accelerated the growth and survival of aquaculture species. The nutritional value of phototrophic bacteria clearly indicated that it could be used as a potential protein supplement. Survival rate of carp increased $96.5 \%$ when PSB was fed at $0.1 \%$ supplemented with commercial feed [13]. Phototrophic bacterial cells that were used in the purification of wastewater utilized as food by plankton, fish, and could also be used as a feed for the cultivation of Artemia salina (brine shrimp). Phototrophic bacteria have some anti-virus compounds that suppress viral diseases of shrimp as well as shellfish [34]. In Japan, gill disease of prawn was prevented completely by adding the anoxygenic phototrophic bacteria in the tank [13]. Addition of three species of PNSB such as, Rhodobacter sphaeroides, Rhodobacter capsulatus and Rhodopseudomonas palustris observed to be increase weight in prawn during grow-out culture and improve water quality when fed with phototrophic bacteria, as ammonia nitrogen was observed to be significantly lower [35]. Seed production of Penaeus chinensis fed a with mixture of four strains of Rhodopseudomonas sp. shows grazing ability of shrimp. The most striking fact was faster metamorphosis (one day earlier) than the pond supplied with normal diet [36]. Further the water quality was observed to be improved with the addition of waste grown PNSB bacterium Rhodovulum sulfi- 
dophilum in of Penaeus monodon larval rearing period [18]. However, the use of various strains of PNSB in production and improvement of nutritional values of live feed need more investigation. Decomposition of waste has been proven to be effective in the increase of nutrients in Tubifex culture. Tubifex spp. grown on such bioprocessed product might have a better organoleptic characteristics and nutritional components, which need further investigation. More comprehensive and detail studies should be conducted to evaluate the bioprocess of hatchery waste as complete diet for the live feed production.

\section{Conclusion}

Purple non-sulfur bacterium, Rhodobacter sphaeroides strain UMS2 play a prominent role in improving the nutritional value of fish hatchery waste during in the bioprocess. The harvesting of bioprocess product from fish hatchery waste could be improved only with the optimum inoculum size and incubation period, $30 \%(\mathrm{v} / \mathrm{v})$ and six days incubation not suitable to increase the nutritional values. Based on the current study, the ability of Rhodobacter sphaeroides strain UMS2 in the utilization of fish hatchery waste is promising. The advantages of using of bioprocess product in live feed supplement to increase growth performance in Tubifex spp. have potentiality for production in controlled environment. The only limitation of this study was duration of the feeding trial. It would be better to have continuous production of Tubifex spp. to get enough biomass for live feed for aquaculture species. The product might have potential as supplement or feed additive in the aquaculture live feed industry.

\section{Acknowledgements}

This research was carried out with the help of the grant from Ministry of Education, Government of Malaysia (Grant Number FRGS 0481-2018). Authors also appreciated the supports from hatchery and laboratory staffs of Borneo Marine Research Institute, University Malaysia Sabah, Kota Kinabalu, Sabah, Malaysia.

\section{Conflicts of Interest}

The authors declare no conflicts of interest regarding the publication of this paper.

\section{References}

[1] Tlusty, M.F., Snook, K., Pepper, V.A. and Anderson, M.R. (2001) The Potential for Soluble and Transport Loss of Particulate Aquaculture Waste. Aquaculture Research, 31, 745-755. https://doi.org/10.1046/j.1365-2109.2000.00497.x

[2] Azad, S.A., Lal, M.T.B.M. and Benjamin, A.-N.B. (2020) Characterization of Finfish Hatchery Waste for Value Added Product. Advances in Bioscience and Biotechnology, 11, 73-79. https://doi.org/10.4236/abb.2020.113006

[3] Lin, Y.F., Jing, S.R., Lee, D.Y. and Wang, T.W. (2002) Nutrient Removal from Aquaculture Wastewater Using a Constructed Wetlands System. Aquaculture, 209, 169-184. https://doi.org/10.1016/S0044-8486(01)00801-8 
[4] Sasikala, Ch. and Ramana, V.Ch. (1995) Biotechnological Potentials of Anoxygenic Phototrophic Bacteria. I. Production of Single Cell Protein, Vitamins, Ubiquinones, Hormones and Enzymes and Use in Waste Treatment. In: Neidleman, S.L. and Laskin, A.I., Eds., Advance in Applied Microbiology, Vol. 41, Academic Press, Cambridge, 173-226. https://doi.org/10.1016/S0065-2164(08)70310-1

[5] Azad, S.A., Vikineswary, S., Chong, C.V. and Ramachandran, K.B. (2003) Rhodovulum sulfidophilum in the Treatment and Utilization of Sardine Processing Wastewater. Letters in Applied Microbiology, 38, 13-18.

https://doi.org/10.1046/j.1472-765X.2003.01435.x

[6] Prasertsan, P., Choorit, W. and Suwanno, S. (1993) Isolation, Identification and Growth Condition of Photosynthetic Bacteria Found in Seafood Processing Wastewater. World Journal of Microbiology and Biotechnology, 9, 590-592.

https://doi.org/10.1007/BF00386301

[7] Azad, S.A., Soon, T.K. and Ransangan, J. (2013) Effects of Light Intensities and Photoperiods on the Growth and Proteolytic Activity in Purple Non-Sulfur Marine Bacterium Afifella marina Strain ME (KC205142). Advances in Bioscience and Biotechnology, 4, 919-924. https://doi.org/10.4236/abb.2013.410120

[8] Azad, S.A., Chin, F.S. and Lal, M.T.M. (2019) Efficacy of Purple Non-Sulphur Bacterium Rhodobacter sphaeroides Strain UMSFW1 in the Utilization of Palm Oil Mill Effluent. Journal of Geoscience and Environment Protection, 7, 1-12. https://doi.org/10.4236/gep.2019.710001

[9] Zhou, Q., Zhang, P., Zhang, G. and Peng, M. (2015) Biomass and Pigments Production in Photosynthetic Bacteria Wastewater Treatment: Effects of Photoperiod. Bioresource Technology, 190, 196-200. https://doi.org/10.1016/j.biortech.2015.04.092

[10] Wen, S., Liu, H., He, H., Luo, L., Li, X., Zeng, G., Zhou, Z., Lou, W. and Yang, C. (2016) Treatment of Anaerobically Digested Swine Wastewater by Rhodobacter blasticus and Rhodobacter capsulatus. Bioresource Technology, 222, 33-38. https://doi.org/10.1016/j.biortech.2016.09.102

[11] Ponsano, E.H.G., Paulino, C.Z. and Pinto, M.F. (2008) Phototrophic Growth of Rubrivivax gelatinosus in Poultry Slaughterhouse Wastewater. Bioresource Technology, 99, 3836-3842. https://doi.org/10.1016/j.biortech.2007.06.063

[12] Hülsen, T., Hsieh, K., Lu, Y., Tait, S. and Batstone, D.J. (2018) Simultaneous Treatment and Single Cell Protein Production from Agriindustrial Waste Waters Using Purple Phototrophic Bacteria or Microalgae-A Comparison. Bioresource Technology, 254, 214-223. https://doi.org/10.1016/j.biortech.2018.01.032

[13] Kobayashi, M. and Kobayashi, M. (2001) Roles of Phototrophic Bacteria and Their Utilization. In: Kojima, H. and Lee, Y.K., Eds., Photosynthetic Microorganisms in Environmental Biotechnology, Springer-Verlag, Hong Kong, 11-26.

[14] Noparatnaraporn, N. and Nagai, S. (1986) Selection of Rhodobacter sphaeroides P47 as a Useful Source of Single Cell Protein. Journal of General and Applied Microbiology, 32, 351-359. https://doi.org/10.2323/jgam.32.351

[15] Burgess, J.G., Tsubaki, K. and Matsunaga, T. (1993) Expression of Yellow Tail (Seriola quinqueradiata) Fish Growth Hormone cDNA in the Marine Photosynthetic Bacterium Rhodobacter SP. NKPB0021. Biotechnology Letters, 15, 111-114. https://doi.org/10.1007/BF00133008

[16] Manju, K.G. and Dhevendaran, K. (1997) Effects of Bacteria and Actinomycetes as Single Cell Protein Feed on Growth of Juveniles of Macrobrachium idella (Hilgendorf). Indian Journal of Experimental Biology, 35, 53-55.

[17] Banerjee, S., Azad, S.A., Vikineswary, S., Selvaraj, O.S. and Mukherjee, T.K. (2000) 
Phototrophic Bacteria as Fish Feed Supplement. Asian-Australasian Journal of Animal Science, 13, 991-994. https://doi.org/10.5713/ajas.2000.991

[18] Azad, S.A., Chong, V.C. and Vikineswary, S. (2002) Phototrophic Bacteria as Feed Supplement for Rearing Penaeus monodon Larvae. Journal of the World Aquaculture Society, 33, 158-168. https://doi.org/10.1111/j.1749-7345.2002.tb00490.x

[19] Azad, S.A., Soon, T.K. and Ransangan, J. (2014) Fermentation of Seaweed Meal Using Rhodovilum sulfidophilum as Aquaculture Feed Supplement. Proceeding INOCIIUM International Conference on Oceanography and Sustainable Marine Production, Kuantan, 28-30 October 2013, 407-408.

[20] Hossain, A., Hasan, M. and Mollah, M.F.A. (2011) Effects of Soybean Meal and Mustard Oil Cake on the Production of Fish Live Food Tubifex Worms in Bangladesh. World Journal of Fish and Marine Sciences, 3, 183-189.

[21] AOAC (2000) Official Methods of Analysis. 15th Edition, Association of Official Analytical Chemists, Williams.

[22] Mudrak, V.A. (1981) Guidelines for Economic Commercial Fish Hatchery Wastewater Treatment Systems. In: Allen, L.J. and Kinney, E.C., Eds., Proceedings of the Bio-Engineering Symposium for Fish Culture, American Fisheries Society, Bethesda, 174-182.

[23] Soon, T.K., Azad, S.A. and Ransangan, J. (2014) Isolation and Characterization of Purple Non-Sulfur Bacteria, Afifella marina, Producing Large Amounts of Carotenoids from Mangrove Microhabitats. Journal of Microbiology and Biotechnology, 24, 1034-1043. https://doi.org/10.4014/jmb.1308.08072

[24] Madigan, M.T. and Jung, D.O. (2008) An Overview of Purple Bacteria: Systematics, Physiology, and Habitats. In: Neil Hunter, C., Ed., The Purple Phototrophic Bacteria, Springer, Berlin, 2-12. https://doi.org/10.1007/978-1-4020-8815-5_1

[25] Azad, S.A. and Lal, M.T.B.M. (2018) Potentiality of Bio-Converted Leafy Vegetable Waste as Aquaculture Feed Supplement. Advances in Bioscience and Biotechnology, 9, 571-583. https://doi.org/10.4236/abb.2018.911040

[26] Soon, T.K., Azad, S.A. and Ransangan, J. (2013) Effect of Light Intensities and Photoperiod on the Production of Extracellular Nucleic Acids in Purple Non-Sulfur Marine Bacterium Afifella marina Strain ME (KC205142). International Journal of Research in Pure and Applied Microbiology, 3, 53-57.

[27] Akintomide, M. and Antai, S. (2012) Enrichment of Irish Potato (Solanium tuberosium) Peels through Solid Substrate Fermentation by Saccharomyces cerevisiae and Aspergillus niger. Journal of Environmental Science, 1, 15-19. https://doi.org/10.9790/2402-0151519

[28] Rajesh, N., Imelda-Joseph and Paul Raj, R. (2010) Value Addition of Vegetable Wastes by Solid-State Fermentation Using Aspergillus niger for Use in Aquafeed Industry. Waste Management, 30, 2223-2227. https://doi.org/10.1016/j.wasman.2009.12.017

[29] Marian, M.P. and Pandian, T.J. (1984) Culture and Harvesting Techniques for Tubifex tubifex. Aquaculture, 42, 303-315. https://doi.org/10.1016/0044-8486(84)90109-1

[30] Wei, Y. and Liu, J. (2006) Sludge Reduction with a Novel Combined Worm-Reactor. Hydrobiologia, 564, 213-222. https://doi.org/10.1007/s10750-005-1720-1

[31] Rodriguez, P., Martinez-Madrid, M., Arrate, J.A. and Navarro, E. (2001) Selective Feeding by the Aquatic Oligochaete Tubifex tubifex (Tubificidae, Clitellata). Hydrobiologia, 463, 133-140. https://doi.org/10.1007/978-94-010-0597-5_15

[32] Herawati, V.E., Nugroho, R.A., Hutabarat, J. and Karnaradjasa, O. (2016) Profile of 
Amino Acids, Fatty Acids, Proximate Composition and Growth Performance of Tubifex tubifex Culture with Different Animal Wastes and Probiotic Bacteria. AACL Bioflux, 9, 614-622. http://www.bioflux.com.ro/aacl

[33] Nwachi O.F. (2013) An Overview of the Importance of Probiotics in Aquaculture. Journal of Fisheries and Aquatic Sciences, 8, 30-32. https://doi.org/10.3923/jfas.2013.30.32

[34] Hirotani, H., Ohigashi, H., Kobayashi, M., Koshimizu, K. and Takashi, E. (1991) Inactivation of T5 Phage by Cis-Vaccenic Acid, and Antivirus Substances from Rhodopseudomonas capsulata, and by Unsaturated Fatty Acids and Related Alcohols. FEMS Microbiology Letters, 77, 13-18.

https://doi.org/10.1111/j.1574-6968.1991.tb04314.x

[35] Qiao, Z.G., Tang, R.Y. and Huang N.Y. (1994) Three Strains of Photosynthetic Bacteria Applied for Prawn Diet and Their Culture Effect. Marine Science, 2, 4-7. (In Chinese)

[36] Cui, J.J., et al. (1997) The Application of the Photosynthetic Bacteria in the Production of the Shrimp Larva Culture. Journal of Ocean University of Quingdao, 27, 191-194. (In Chinese) 